Varga Tamás ${ }^{1}$

\title{
Hagyományos oktatási módszerekre optimalizált komplex tananyag távoktatási tananyaggá történő transzformálásának, fejlesztésének lehetőségei és tapasztalatai
}

\author{
Opportunities and Experiences in the Field \\ of Transformation of Traditional Training Materials \\ to E-learning Contents
}

\begin{abstract}
Absztrakt
Napjainkban egyre inkább elfogadottá válik az oktatás-képzés és kiképzés terén, hogy a hagyományos oktatási és képzési folyamatokat alternativ- vagy atipikus módszerekkel egészitik ki, vegyitik (vegyes képzés), vagy teljes mértékben elektronikus környezetbe, platformokra helyezik át. Egyrészt ez extraként járul hozzá az oktatási folyamat eredményességéhez, további információ megosztásával vagy az oktatott témához relevánsan kapcsolódó kép, hang esetleg videóanyag megosztásával vagy egyfajta igényként jelenik meg, hogy a szükös időkeretek mellett flexibilis lehetöséget biztositson a tanuláshoz. Bármely oktatandó témakört alapul véve, a tanulási folyamatot támogató tananyag összeállitása és egy egységbe szerkesztése a folyamat legfontosabb része, hisz az ebben lefektetett alapok mentén megy végbe a tanulási folyamat (egy része). Tanulmányom célja, hogy számba vegye mindazon elemeket a tanítási folyamatban, amelyek elengedhetetlenül fontosak, és megvizsgálja azok beillesztésének lehetöségét távoktatási keretek közé, úgy, hogy értékük és eredményességük a tanulási folyamat vonatkozásában lehetöleg ne sérüljön.
\end{abstract}

Nemzeti Közszolgálati Egyetem Hadtudományi Doktori Iskola, doktorandusz - National University of Public Service, Doctoral School of Military Sciences, PhD student, e-mail: varga.tamas.vktt@gmail.com, ORCID: https://orcid. org/0000-0003-2821-6674 
Kulcsszavak: tradicionális oktatás és képzés, atipikus módszerek, távoktatás, tananyagtranszformáció

\begin{abstract}
Nowadays it is widely accepted and known that traditional education and training contents are combined/blended with or replaced by alternative (e-learning) training materials, placing the learning process into a virtual environment. On the one hand, this kind of transformation can contribute to the success of the learning process through sharing extra relevant information, media content; on the other hand, e-learning methods provide flexible training opportunities in our fast-paced world. Regardless of the type of the training content, the most important part of the procedure is the design and development of the training materials, because this phase determines the entire training process, the defined basic principles play vital roles in success. My aim is to take into account the elements of the learning process - which are very important both in traditional and alternative training methods - and analyse the opportunities of its transformation into e-learning content ensuring success.
\end{abstract}

Keywords: traditional education and training, alternate methods, distance learning, transformation of traditional training contents

\title{
Bevezetés
}

A hagyományosan frontális osztálymunka módszerére épülö tananyag távoktatási környezetbe történő áthelyezésére számos módszer létezik, a módszer kiválasztása attól függ, hogy az alapokat kialakító tanár, oktató a technikai lehetőségek függvényében mely lehetőséget látja a legoptimálisabbnak a megcélzott tudás átadásához. A következő́kben vizsgáljunk meg néhány napjainkban elterjedt formát - az általam, természetesen teljesen szubjektív vélemény alapján kialakított hatékonysági sorrend alapján - amelyek többé kevésbé dominálják a távoktatás területét.

\section{Távoktatási megközelítésű módszerek rövid összehasonlító vizsgálata}

Tananyagok elektronikus formában történő megosztása, számonkérés elektronikus környezetben (dokumentum-megosztó portál vagy távoktatási keretrendszer alkalmazásával)

Ezt a koncepciót követi a Magyar Honvédségben alkalmazott minősítő és fokozati vizsgarendszer, vagy a tisztképzés „távoktatási” katonai alapismeretek elsajátítását 
célzó részképzése, ahol az adott személy rendfokozati vagy szakmai végzettségi mutatóinak megfelelően kell a távoktatási keretrendszerbe feltöltött elektronikus formájú szabályzatok, szolgálati könyvek, esetleg egyetemi, főiskolai jegyzetek alapján elsajátítani az ismereteket. Ezt követően egy elöre meghatározott időpontban és helyen a távoktatási keretrendszerben összeállított teszt végrehajtásával kell bizonyítani a meghatározott ismeretanyag elsajátítását. A teszt végrehajtását esetlegesen próbatesztek segítik, amelyek inkább a tesztkérdések technikai jellegzetességeire (igaz-hamis, szövegkiegészítés, több opcióból választás) készít fel, mint sem egyfajta visszajelzésként szolgálna az elsajátított tananyaggal kapcsolatosan.

Legnagyobb hátránya a tanár-diák kapcsolat teljes hiánya, az esetleges konzultációk nem képezik részét a tanulási egységnek.

\section{Vlog - videókonferencia rögzített formában}

Egyre gyakrabban tapasztalható, hogy a hagyományos frontális osztálymunkát, az ismeretek közlését a tanárok videófelvételek formájában rögzítve osztják meg a tanulókkal, amelyek már egy jóval komplexebb formáját mutatják a távoktatás lehetőségének. Egy tanulási egységben foglalják össze az átadandó tudásanyagot (prezentáció, kiegészítve beépített videó- és hanganyaggal), a tanár szükségesnek vélt és fontos magyarázatát, meglátásait, esetleges javaslatait a tudás további kibővítésére.

Ez a módszer jelentősen hozzájárul a tananyag „fogyaszthatóbbá" tételéhez, egy prezentációs technikák alkalmazásában jártas előadó esetén élményszerü folyamatot eredményez, amely növeli a hallgatóság egyéni motivációját az elsajátítás, feldolgozás irányába. Hátránya, hogy a kommunikáció csak egyirányú, az esetleges konzultációkat és számonkérést szintén a tanulási egységen kívül szervezik meg.

\section{Videókonferencia - virtuális tanterem}

Az előző módszer egy kifinomultabb verziója, természetesen nem a Skype vagy más videóchat formájú közlésre gondolok elsősorban. Számos olyan virtuális tanteremalkalmazás létezik már (például BigBlueButton), amely képes egy felületen teret adni a megosztandó írott (MS PPT) tananyagnak, az előadóról rögzített videóképnek, a többirányú kommunikációt lehetővé tévő konferenciamenedzsment-opcióknak vagy chatfelületnek, és esetlegesen még kiegészítésként értékelések, kérdésekre adott válaszok statisztikai eredményei is megoszthatók. A módszer teljes spektrumában történő alkalmazása még nem elterjedt, de a Magyar Honvédségen belül (MH Béketámogató Kiképző Központ) precedensértékü, hogy nemzetközi kiképzési rendezvények (Békeműveleti együttmüködési tanfolyam - PSOCC) esetén alkalmazzák a new york-i ENSZ-központ részéről felkért előadó előadásához. 


\section{Komplex távoktatási tanegység alkalmazása távoktatási keret- rendszerben}

Véleményem szerint a hazai távoktatás jövője lehet, még egy ideig, hisz a jelenlegi Magyar Honvédségben folyó távoktatási projektek (Önkéntes tartalékos képzés, Önkéntes honvédelmi előképzés) alapját adó SCORM (Sharable Content Object Reference Model - megosztható tartalmi objektumok hivatkozási modellje) referenciamodell már mintegy két évtizedes múltra tekint vissza, és vezető kutatók is a modell hanyatlását prognosztizálják, annak sok esetben nehezen kezelhető kötöttségei miatt (például egy-egy esetleges tananyag-módosítás miatt a teljes tananyag „újrapublikálása" szükséges, ami a korábbi statisztikai adatokkal való kapcsolatot teszi lehetetlenné).

Mindezen hátrányok ellenére azonban ez a modell fogja leginkább egy egységbe a tanulási folyamat fontos alkotóelemeit, mint adminisztratív információk (tananyag tárgya, relevanciája, kijelölt tanulási célok stb.), tananyag, narráció, kiegészítő médiaelemek (kép, animáció, videó), valamint a tananyag elsajátítását felmérő tesztrendszer és az ahhoz tartozó azonnali kiértékelés. Teljesen e-learning jellegű tananyag esetén a kurzushoz csatolható „oklevél” opcióval (JAVA-alkalmazás), az eredményes teszt alapú elsajátítást követően a névre szóló oklevél automatikusan elérhetővé válik a tanuló részére, mintegy igazolva a végrehajtást.

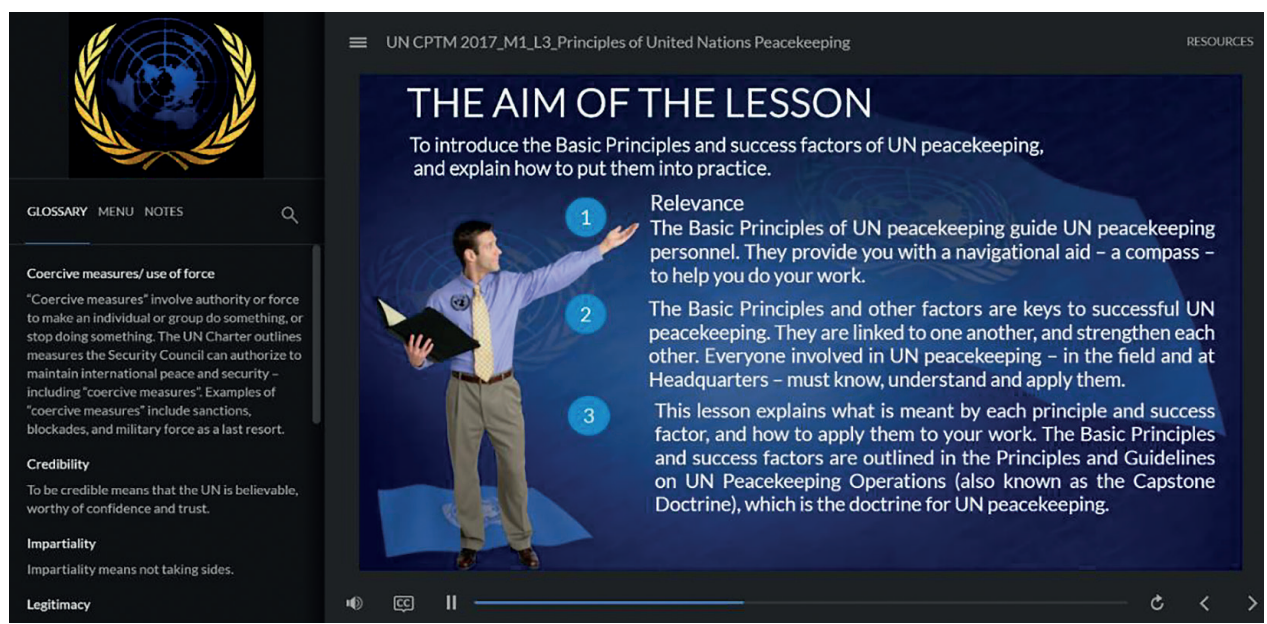

1. ábra: SCORM-referenciamodell alapú távoktatási tananyag felülete (MH projekt) 


\section{Egy hagyományos - frontális osztálymunka alapú - tanfolyam tananyagának távoktatási tananyaggá történő átalakítása}

\section{A tananyagszerkesztésben részt vevő szakértők és feladataik}

Optimális esetben egy komplett távoktatási tananyag kidolgozásához, létrehozásához négy funkciót (feladatkört) ellátó, betöltő személyre, személyekre van szükség, természetesen ez erőteljesen függ az adott szervezeti elem humánerőforrás-ellátottságától:

- Projektmenedzser - a kidolgozás teljes spektrumát átlátó, a szükséges adminisztratív feladatokat és egyeztetéseket végrehajtó személy;

- Témakör-, tananyagszakértő́ (Subject Matter Expert - SME) - aki a szakterületet mélységeiben ismeri, képes a tananyag keretét adó információkat (tárgy, cél, módszer, tudásanyag mélysége stb.) meghatározni, ha az adott azt feldolgozni, a tanulási folyamatot vizionálni, a tananyag „forgatókönyvét” összeállítani, valamint a kidolgozás folyamatát javaslataival támogatni;

- Tananyagszerkesztö - aki a forgatókönyv alapján a tananyagszerkesztő programban létrehozza a távoktatási tananyagot folyamatosan konzultálva az SME-vel;

- Grafikus - aki a megrendelő elképzelése alapján a grafikai elemeket és dizájnt kialakítja, létrehozza, valamint az esetleges beépülő aminációkat elkészíti. A grafika és színsablonok alapos kidolgozása sokak részére nem képez nagy fontosságot, azonban a tananyag elsajátítása, élményszerüségének biztosítása vonatkozásában kiemelt jelentőségủ. Sok esetben külön grafikust csak a szükséges humán erőforrással rendelkező cégek tudnak felmutatni, feladatkörét számos esetben a tananyagszerkesztő látja el.

Természetesen abban az esetben, ha egy szervezet nem rendelkezik megfelelő szintü erőforrásokkal, a fenti feladatokat egy személy is végre tudja hajtani, azonban ebben az esetben a kész produktum „teljessége” szenvedi el a következményeket. Ha szakértő nem áll rendelkezésre, a tananyag kidolgozottsága és hitelessége szenved csorbát, nem biztos, hogy a kitüzött célok elérését leginkább támogató tananyagtartalmat állítanak össze és szerkesztenek egy egységbe, a kész anyag nem illeszkedik a célállomány szintjéhez, fölétervezés esetén annak elsajátítása túl nagy kihívást jelent, alátervezés esetén pedig nem ad- vagy jóval kevesebb új elsajátítható ismeretet. A tananyagszerkesztő és grafikus páros a tananyagdizájnt és annak technikai hátterét biztosítja, hiányuk esetén természetesen egy jó informatikai érzékkel rendelkező tanár is képes viszonylag hamar müködőképes távoktatási tananyagot előállítani elfogadható szinten. Azonban egy komplex, több animációt, videóanyagot magába foglaló, hivatkozásokkal teli, bonyolult tesztrendszerekkel megfüszerezett, tetszetős és érdeklődést keltő tananyagot csak professzionális tudással rendelkező szakállomány tud összeállítani. 
Tanulmányomnak nem célja, hogy a tananyag "megszületéséhez” vezető út minden egyes részletét bemutassa, a tanulmány terjedelmi korlátai ezt nem is tennék lehetővé, de az kijelenthető, hogy egy rendkívül komplex, szerteágazó folyamat (ADDIE-modell) eredményeként áll össze a távoktatási tananyag forgatókönyve és annak projektfájlba ültetett végeredménye.

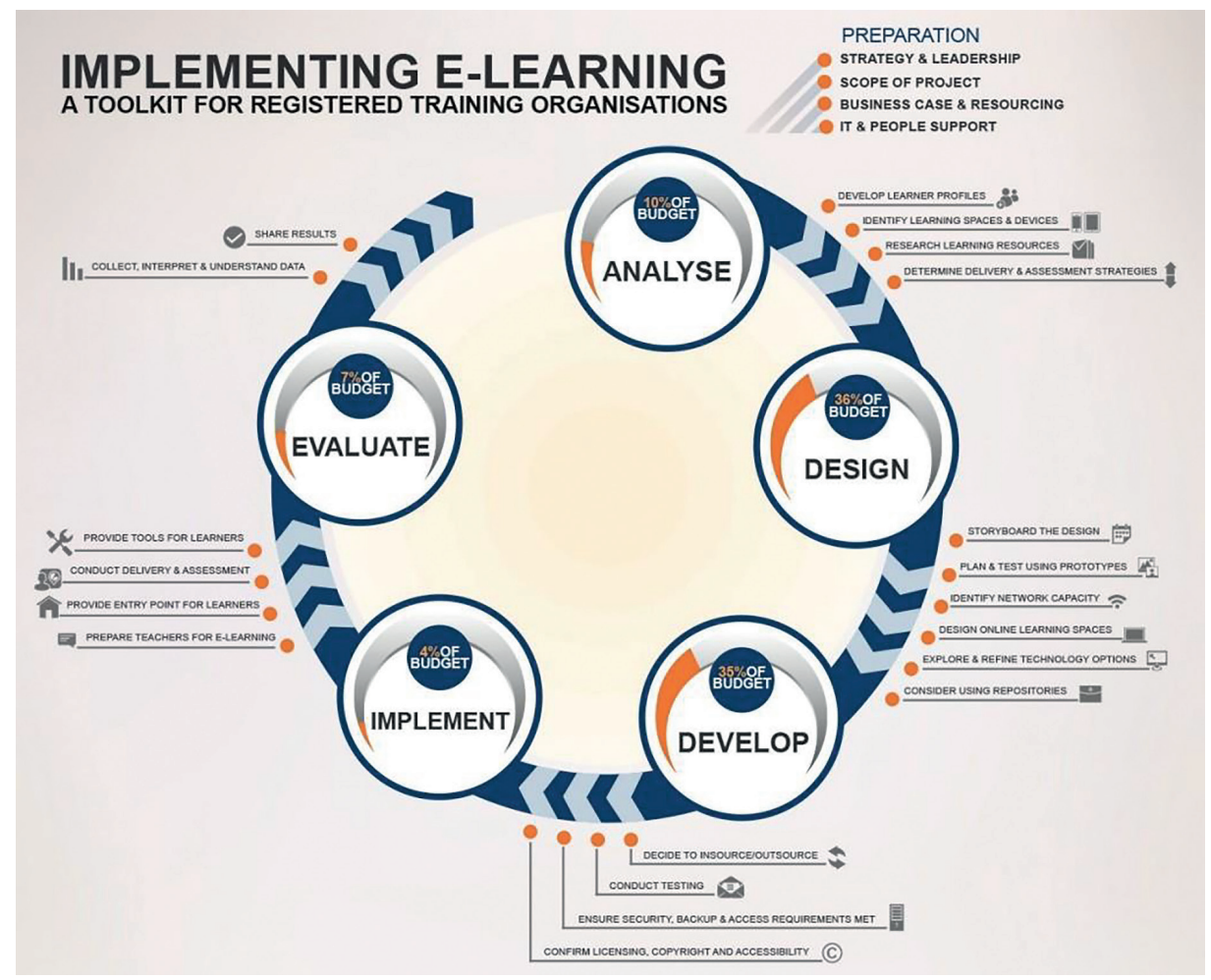

2. ábra: Az ADDIE-modell lépései és a tananyag „elöállitás" költségterhei

Forrás: Bates, Tony: Is the ADDIE model appropriate for teaching in a digital age? 2014, www.tonybates. ca/2014/09/09/is-the-addie-model-appropriate-for-teaching-in-a-digital-age/ (Letöltve: 2019. 05. 27.)

Egy jól kidolgozott távoktatási tananyag forgatókönyve tartalmazza mindazon elemeket, amelyek a tananyag szerves részeként beépülnek a tananyag projektfájlba, úgy mint:

- A tananyagegység célját.

- A tananyag relevanciájára utaló információkat.

- A tananyag elsajátításával elérendő célokat (learning outcomes).

- Tananyagtérképet vagy menürendszert, ahonnan a fö tanulási egységek, fejezetek elérhetők, ezzel egy átlátható, kezelhető felületet biztosítva a tanuló részére. 
- Javaslatot a tananyag indítására, ami lehet egy mottó, releváns videóanyag, vagy egy esetleges feladat a hallgatóság részére, a figyelemfelkeltés, a motiváció stimulálása érdekében a tananyag irányába.

- A tananyagba épített médiaelemek (kép, videó, hang, animáció stb.) leírását és elérhetőségét, a tananyagba épités módszerét (például stabil látható elemként, lenyitható kiegészitésként vagy hiperhivatkozással, felugró ablakban jelenik meg).

- A tananyagba beépített aktív tanulási elemek leírását és alkalmazásuk formáját (esettanulmány-vizsgálat, releváns videóelemzés és az azokhoz tartozó kérdés-válaszpárok, esszéválasz kidolgozása stb.).

- A tananyagtartalmat, lehetőleg szerkeszthető, kész formában (MS Word, MS PPT) a szükséges illusztrációkkal, képanyagokkal ellátva, annak érdekében, hogy a tananyagszerkesztő az SME által elgondoltak szerint alakíthassa ki az egyes részegységeket.

- A tananyagtartalomhoz tartozó narrációt, magyarázó szöveget, amely vagy a dia mellé a "megjegyzések" menüben rögzíthetö, vagy hangszintetizátor alkalmazásával hang alapú narrációként alkalmazható. (Jelenleg a magyar nyelvű narráció elérhetősége eléggé korlátozott, de a vezető fejlesztőcégek [Neospeech] által adott információk alapján 2-3 éven belül 1-1 minőségileg is megfelelő magyar férfi és női hangopció elérhető lesz.).

- A tananyag összefoglalására vonatkozó instrukciókat.

- A tananyag-értékelés végrehajtására vonatkozó instrukciókat, javasolt értékelési kérdéseket vagy kérdéstípusok leírását. Első esetben a fejlesztő csoport tananyagszakértője konkrét kérdéseket dolgoz ki az általa legmegfelelőbb kérdéstípusok (feleletválasztásos, igaz-hamis, aktívfelület jellegü stb.) alkalmazásával, utóbbi esetén a tananyagszerkesztő állít össze kérdéseket a tananyagtartalom felhasználásával.

- Opcionálisan kidolgozható „kulcsszavak és definíciók” leírását, amely olyan esetben lehet hasznos, amikor a tanulók nagy mennyiségü definícióra való hivatkozással találkoznak a tananyagban, de azok leírása csak túlbonyolítaná a tananyagot. A "Glossary” legördülő menüjében az adott definícióhoz tartozó minden releváns információ elhelyezhető.

- A weboldalaknál "GYIK - gyakori kérdések és válaszok” opcióként ismert információkat, amelyek szintén beépíthető elemként jelennek meg.

- Referenciaanyagok leírását és elérhetőségeit.

- További, a tanulási folyamatot hasznosan kiegészítő tananyagtartalmak hivatkozásait, amelyek aktív hiperhivatkozásként megnyithatók a tananyagból.

- További számos - a tananyagszakértő által fontosnak vélt - elemet, amely képes a tananyaggal szemben támasztott követelményeket teljesíteni, a tanulók részéről a tanulási célkitüzéseket elérni.

A fenti szerteágazó tananyagtartalom egy komplex tanulási folyamat formájában történő „megálmodása” tehát a tananyag szakértőjének feladata, míg a tananyagszerkesztő és a grafikus a szakértő által megálmodott folyamatot a szoftver adta lehetőségek teljes felhasználásával kidolgozza és a távoktatási keretrendszerben működőképessé teszi. 


\section{ADL Modulok - a tanulási folyamat legkisebb egységei}

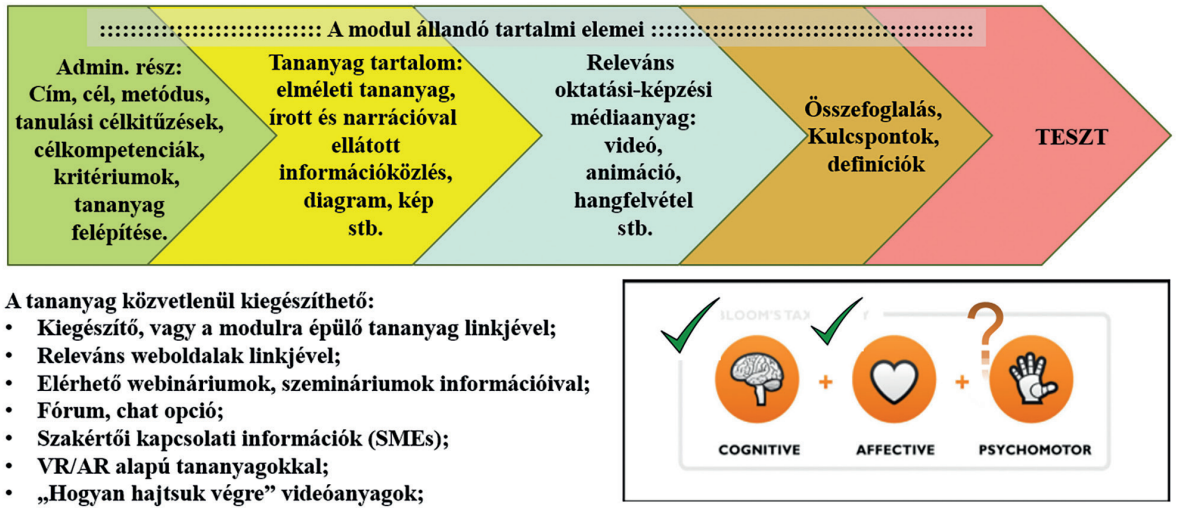

3. ábra: Távoktatási tananyag elvi struktúrája

Forrás: a szerző szerkesztése

\section{Távoktatási tananyagszerkesztés szerkesztői felületei}

Azt gondolhatnánk, hogy a távoktatási tananyagfejlesztő munka oroszlánrészét a releváns tananyagtartalom gyüjtése, folyamatba szerkesztése, a kiegészítő-elemek, mint a médiatartalom kiválasztása vagy az elsajátítás mérési rendszerének kialakítása jelenti, amely részben igaz, de a végtermék és annak használhatósága szempontjából nem kevésbé fontos a tananyagszerkesztéshez alkalmazott tananyagszerkesztő szoftver professzionális ismerete sem.

A piacon számos felhasználóbarát szoftver érhető el, amelyek az esetek nagy százalékában licensz vásárlását követően szabadon használhatók. Természetesen a távoktatási keretrendszerek is kínálnak egyfajta korlátozott opciót - így az $\mathrm{MH}$ által alkalmazott ILIAS-keretrendszer is, beépülő szolgáltatásként limitált SCORMszerkesztőt - de azok lehetőségek és minőség szempontjából messze elmaradnak a célirányosan fejlesztett tananyagtartalom-szerkesztő szoftverektől.

A következőkben röviden a tananyagszerkesztő szoftver fő munkafelületeit szeretném bemutatni, amelyek a legtöbb szoftver esetében többé-kevésbé azonosak, de a végtermék szempontjából kiemelt jelentőséggel bírnak. 


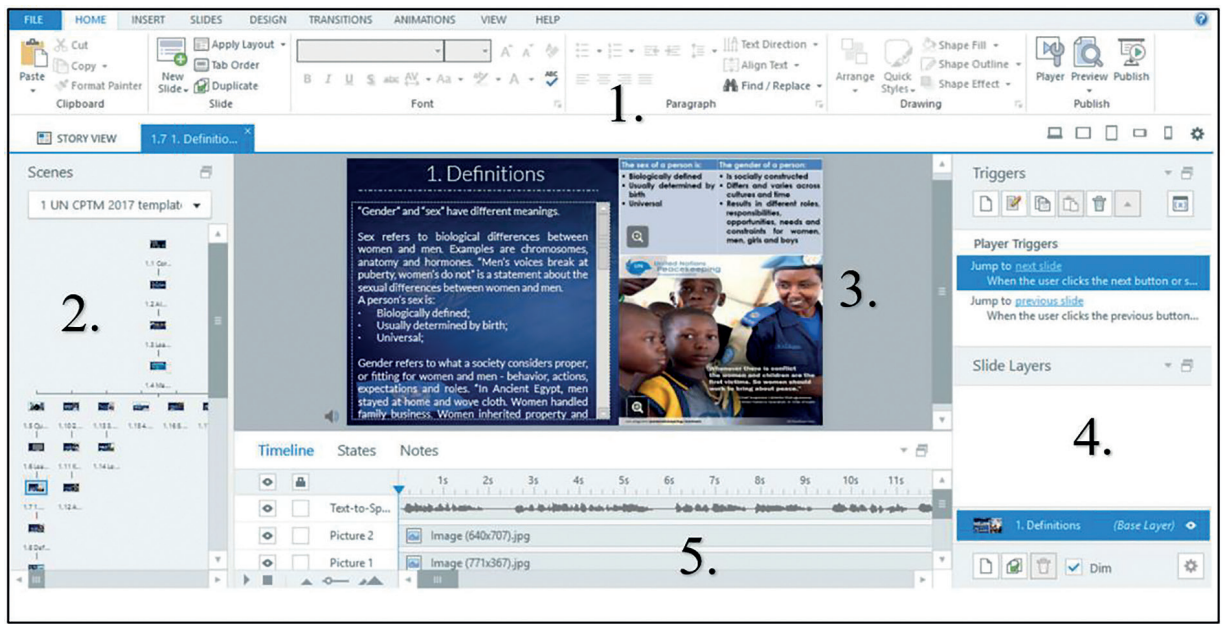

4. ábra: Articulate Storyline 360 távoktatási tananyagszerkesztő szoftver szerkesztői felülete

Forrás: a szerző felvétele

Első ránézésre kijelenthető, hogy a felület erős azonosságot mutat a Microsoft Powerpoint szerkesztői felületével, ami természetesen igaz, vélhetően abból a megfontolásból, hogy az oktatás és képzés területén tevékenykedő szakemberek múltbéli és jelenlegi tevékenységük során valószínüleg gyakran alkalmazzák a programot tevékenységük támogatásához, tehát a szerkezeti-funkcionális müködés elsajátítása nem okozhat gondot.

A munkafelület 1. számú része az, ami a legnagyobb hasonlóságot mutatja az MS PPT-programmal. Itt érhetők el a jól ismert formázási elemek, a diák dizájnelemeinek szerkesztési felületei, médiaanyagok beillesztésére szolgáló opciók gombjai, a tananyagtartalom esetleges aminációs beállítási felületei.

A 2. felület a tananyagtartalom aktuális struktúráját és a tartalmak közötti hivatkozások kapcsolati hálóját jeleníti meg, egyfajta átlátható képet adva a szerkesztő részére a tananyag felépítéséről.

A 3. felület az adott szerkesztés alatt álló dia felületét mutatja annak minden releváns tartalmával, esetlegesen a diához kapcsolt kiegészítő-elemekkel (kis hang ikon a dia bal alsó sarkában a diához kapcsolt narráció funkció aktivitását jelzi).

A 4. felület meglehetősen komplex tartalmát tekintve, itt szerkeszthetők a diák egymáshoz füződő hiperhivatkozásai, a diába épített médiaelemek vezérlési opciói, a tesztrendszerek kérdései és azok pontozási rendszere, valamint az egy dia felületére épülő kiegészítő felületek (layerek), amelyek csak bizonyos elemek (például tesztértékelés eredménye következtében „sikeres vagy sikertelen” felület) aktivizálódása esetén jelennek meg. 
A tananyagszerkesztő program 5. számú felületén állítható be az egy szerkesztési dián található elemek időzítése és sorrendje, az aktív és változtatható státusszal rendelkező elemek háttérinformációi, illetve a diához tartozó "Notes” felületen helyezhető el a diához tartozó úgynevezett magyarázó szöveg, amelyböl a szoftver szükség esetén a „text-to-speech" opcióval narrációs hanganyagot tud generálni.

Mint látható, a munkafelület rendkívül gazdag lehetőségek és opciók tekintetében, egy alaposan kidolgozott tananyag-forgatókönyv vagy illusztrációs jegyzék esetén egy szakképzett és rutinos szerkesztő hatékony és eredményes távoktatási tananyagot tud kidolgozni. Természetesen vannak még "vak" területek, a hagyományos képzés egyes aktív részei, mint tanár-diák valós idejü diskurzus vagy csoportos kollaboratív munka, ami még nem elérhető opció a szerkesztőprogram vonatkozásában, de meggyőződésem, hogy a szerkesztőszoftverek fejlesztői csoportjai már dolgoznak a megvalósíthatóság egyes kérdésein.

\section{Távoktatási tananyagszerkesztő program alkalmazását szolgáló/ támogató szolgáltatások}

A tananyagszerkesztő programok fejlődése más informatikai alkalmazásokhoz hasonlóan töretlen, a napi professzionális használathoz szükséges oktatás iránti igény folyamatos, ami nemcsak a kezdeti, úgynevezett első alkalmazásba vétel szempontjából fontos, hanem a bevált gyakorlatok megismerése szempontjából is, abban az esetben például, ha a szerkesztő a tananyagszakértő által megálmodott részfolyamatot nem képes elsőre transzformálni a szoftver adta keretek közé.

Egy komoly szakmai múlttal és folyamatos fejlesztői gárdával rendelkező cég nemcsak az alapszintủ elsajátításhoz kínál - ingyenes vagy költségtérítéses - hagyományos/ távoktatási jellegü képzési lehetőségeket, de a szakértői megoldások megismeréséhez, közösségformáláshoz is hozzájárul webináriumok, fórumfelületek biztosításával, ezzel elősegítve egy elégedett, hatékony tananyagszerkesztő csoport létrehozását. 


\section{Upcoming Webinars (In English Only) \\ May 2019 \\ Friday 24 \\ $5 \mathrm{pm}-6 \mathrm{pm}$ CEST \\ Articulate Staff \\ Everything You Need to Know About the New Scenario Block in Rise 360 \\ Easily add branching scenarios to your Rise 360 projects with the new scenario block. We'll walk through choosing Content Library 360 characters, adding dialogue, responses, and feedback to create a compelling and interactive scenario.

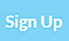 \\ $8 \mathrm{pm}-9 \mathrm{pm}$ CEST Tom Kuhlmann \\ Quick Tips \& Tricks: Episode 5 \\ Looking for some quick tips and tricks? In this session, we'll answer some of the week's top questions from the Articulate community. \\ The sessions are a bit less formal and cover a range of topics. \\ 5. ábra: Articulate Storyline 360 képzési lehetöségek felülete \\ Forrás: Articulate Storyline 360 hivatalos weboldal, Képzési lehetőségek, https://360.articulate.com/training} (Letöltve: 2019. 05. 17.)

\section{Távoktatási tananyagszerkesztés tapasztalatai és kihívásai}

A hagyományos oktatási-képzési eljárásokra kidolgozott tananyag átültetése távoktatási keretek közé egyrészről egy jól kidolgozott forgatókönyvet vagy illusztrációs jegyzéket, másrészről kellő időt, türelmet és a távoktatási tananyagszerkesztő szoftver professzionális ismeretét igényli.

Az eddigi távoktatási tananyagfejlesztési projektekben való részvételem során találkoztam a lehető legopcionálisabb, minden szempontból előkészített projekttel, másrészröl olyan tananyagfejlesztői feladattal is, amely vonatkozásában csak oktatási terület megnevezése volt adott, és amelyben a komplett tananyagot - kezdve a tananyagstruktúrától, dizájnelemektől, a tartalmi elemeken és médiaanyagokon keresztül egészen a tesztrendszerekig - az alapoktól kezdődően kellett felépíteni. Minden egyes munka egyedi jellemzőkkel bír, de általánosan, minden távoktatási tananyagfejlesztési munka esetében alkalmazható tapasztalatok természetesen születtek.

- A tananyag alapadatainak, mint „keret” meghatározása a megrendelő részéről - a munka megkezdésének kiemelt fontosságú része, hogy a tananyagot megrendelő szervezet alapvető elképzeléseit, kritériumait megvitassák és rögzítsék. Ebben a fázisban szükséges kidolgozni a tananyag tárgya, célja, követelményei tartalmát, meghatározni a célközönség képzési szintjét és a tananyag 
nagybani terjedelmére vonatkozó instrukciókat. Számos tananyagfejlesztői projekt esetében ezen információkat a megrendelő részéről nem adják meg és dolgozzák ki, mert a tananyagfejlesztői munka szerves részét képezi egy illusztrációs jegyzék (mint forgatókönyv a későbbi távoktatási tananyaghoz) kidolgozása. Az ilyen jellegü stratégia azt eredményezheti, hogy a kidolgozandó tananyag nem minden tekintetben fedi a megrendelő elképzeléseit, biztos, hogy a kidolgozást követően kisebb nagyobb átdolgozások szükségesek. Tapasztaltam olyan esetet tananyagfejlesztői tevékenységem során, ahol az illusztrációs jegyzék elfogadása ellenére is a megrendelő számos komplett tananyagegységet átdolgoztatott.

- A feldolgozandó és javasolt dokumentumok kijelölése - a tananyag tartalmi elemeinek kidolgozása érdekében fontos, hogy a felhasználásra tervezett írott források jegyzékét összeállítsák, és a megrendelő által írásban elfogadják. Amennyiben egy-egy tananyag kidolgozásánál aktív szerepet játszó tananyagszakértő a tartalmi elemeket önállóan tervezi kidolgozni, akkor értelemszerüen a tananyag létrehozása jóval több időt vesz igénybe. A leghatékonyabb megoldás lehet, ha a tananyag létrehozásához hiteles szerzőktől, már korábban lektorált anyagokat választunk - természetesen kiemelt figyelmet fordítva a hivatkozások pontos feltüntetésére - mivel ilyen esetben nem érheti támadás a tananyagot tartalmi szempontból, illetve csökkenthető a kidolgozásra tervezett idő, ami sok esetben extra nyomásként nehezedik a kidolgozó állományra.

- A dizájnelemek pontosítása - a tényleges kidolgozó munka elkezdése előtt a mintaanyagok - adminisztratív diák, fő tananyagelemek, diatípusok, mintatesztek stb. - kidolgozása elengedhetetlen, mivel sok extra munka és idő spórolható meg ezzel a későbbiekre való tekintettel. A színpaletta módosítása, betűtípusok és méreteik átalakítása egy-egy nagyobb terjedelmű távoktatási tananyag (több modul, sok száz diával) vonatkozásában extra munkaórákat, napokat jelenthet a kidolgozó állomány számára.

- A médiaelemek arányainak és jellemzőinek pontosítása - a tananyag arányainak meghatározása az írott és médiaanyag vonatkozásában rendkivül fontos tényező, mivel egyrészről a megrendelő elképzeléseit - az esetek nagy részében sok írott anyag, kevesebb média-kiegészítéssel - egyeztetni szükséges a távoktatási eljárásokra vonatkozó specifikumokkal. Nincs annál rombolóbb módszer a tanulói érdeklődés és motiváció fenntartása terén, mint amikor diák tucatjain keresztül a tanulónak csak írott tananyagot szükséges feldolgoznia és elsajátítania. Az adott témakörhöz tartozó releváns médiatartalom, legyen az egy-egy sokatmondó kép vagy videóanyag megfelelő méretben és minőségben való megtalálása és kiválasztása, természetesen figyelembe véve a kapcsolódó licenszjogokat, legalább akkora odafigyelést és munkát igényel, mint a tananyagtartalom szerkesztése és beillesztése. A megfelelő médiatartalmaknak módszertani szempontból is kiemelt jelentőségük van, mivel elősegítik, támogatják az ismeretanyag beépülését és későbbi egyszerủbb felidézését, előhívását a tanulók részéről.

- Tesztrendszerek tartalmi és formai követelményei - pedagógiai szempontból a tesztrendszerek pontos kialakításának nemcsak a tananyagtartalom 
ismeretszintjének felmérése a célja, hanem az is, hogy a tanulók tanulási folyamatához hozzájárulva, pozitív eredmény esetén további fejlődésre ösztökélje a tanulót, negatív eredmény esetében pedig visszajelzést adjon a még problematikus területekre vonatkozóan. A tesztek teljesítése nem lehet extrém nehézségű, nem tartalmazhat félreérthető vagy nehezen megérthető kérdéseket, nem lehet célja a tanulók kellemetlen, esetleg méltatlan helyzetbe hozása. A tesztkérdéstípusok pontos meghatározása minden esetben a megrendelő feladata.

- Késztermékre vállalt, módosítással kapcsolatos kötelezettségek - optimális esetben a tananyag éles alkalmazásba vételét hosszas és alapos tesztidőszak előzi meg, ahol a tananyagtartalom mellett az egyes funkciók müködőképességét is megvizsgálják. Természetesen egy nagyobb volumenü tananyag esetén, mikor a kivitelezésre szánt idő erősen alultervezett a megrendelő részéről, nincs túl sok idő és lehetőség a produktum alapos ellenőrzésére, a szükséges módosítások végrehajtására. Ezen felül adódhat olyan eset - a helyzet gyors változása miatt, például szervezeti és személybeli változások - amely miatt vagy az átadást megelőzően kell a tananyagot módosítani, vagy a megrendelő kéri a kész átadott produktum módosítását. A félreértések és problémák elkerülése érdekében a szerződéskötési fázisban javasolt az esetleges átadást követő módosítások jellegének és körülményeinek rögzítése, például az átadást követö 1-3 hónapon belül a tananyagtartalom egy meghatározott (körülbelül $1-5 \%)$ részére vonatkozó javítási kötelezettség rögzítése.

A tananyagtartalom áthelyezésének technikai, valamint módszertani kihívásait - például tananyaghoz illeszkedő színpaletták, betűsablonok és méretek kiválasztása, szövegtördelési opciók, nagy mennyiségủ adatot tartalmazó képanyagok problematikája stb. - tucatnyi oldalon keresztül lehetne részletezni, de jelen esetben ez nem célom, egy eredményes tananyag-transzformáció alapvető buktatóit és tapasztalatait a fentiekben ismertettem és bemutattam.

\section{Összegzés}

A hagyományos oktatási és képzési eljárásokra optimalizált tananyag gyors és lehetöleg minden szempontból azonos tartalmú, hiteles átformálása az egyik legfontosabb kérdése a jelenlegi távoktatási eljárásoknak. A jelenlegi alkalmazott referenciamodellek, föleg a SCORM-modell, ha szabad így kifejezni magunkat, nem egészen „befogadó”, jellegét és természetét tekintve. Nem illeszthetők be a már megkezdett tanfolyam rendszerébe új ismeretek, új tananyagtartalmak, csak a komplett projektfájl átírásával és „újrapublikálásával”, ami nem támogatja sem a tananyagtartalom átlátható evolúcióját (egy tananyagegységen belül), sem a statisztikai adatok folyamatosságát és összehasonlíthatóságát.

Bizonyos, hogy a fejlesztők már dolgoznak olyan komplex referenciamodellek kialakításán, amelyekbe jóval könnyebben illeszthetők be a friss tananyagtartalmak, továbbá extra opcióikkal, mint a tanulási folyamat személyre szabhatóságával is 
hozzájárulnak az eredményességhez. Meggyőződésem, hogy az ilyen jövőbeni totális tanulási struktúrák (Total learning architecture - TLA - mint új referenciamodell) alapjaiban fogják átalakítani mind a tanárok, mind a tanulók nézeteit a távoktatási eljárásokról és módszerekről, ami segíthet az eddigi negatív sztereotípiák megváltoztatásában.

\section{Internetes források}

Bates, Tony: Is the ADDIE model appropriate for teaching in a digital age? 2014, www. tonybates.ca/2014/09/09/is-the-addie-model-appropriate-for-teaching-in-adigital-age/ (Letöltve: 2019. 05. 27.)

Articulate Storyline 360 hivatalos weboldal, Képzési lehetőségek, https://360.articulate.com/training (Letöltve: 2019. 05. 17.) 